\title{
SEEDS TRAVEL
}

Plotting a route.

\section{BY BETH GODER}

$\mathrm{H}$ ajar piloted the mech over vast mountains, through meadows lush with grasses that were almost like those of Earth, except for their orange tips. She travelled through dense forests and snowscapes heavy with wind.

The mech was like an extension of her body, never tiring, wrapping around her like a seed pod protecting its cargo.

Hajar reviewed the data from the soil samples gathered by the mech's feet. A rich composition of minerals in this region, but not enough nitrogen for farming.

In her pocket rested a blue stone.

When Hajar was six, back on Earth, she brought her father a seed. "What's this?" she asked.

He scooped her onto the kitchen counter and kissed her nose. "That's a boxelder maple seed. Look at how it's held within this thin layer, like a paper coat."

"How did it get here?"

Her father told her that seeds travel by wind and water, in the hard shells of nuts and blankets of fruit, carried on the coats of animals or mashed within their digestive tracts, pulled underground by insects, buried by squirrels, scattered by the dual forces of pressure and gravity.

Blackberry plants stretch their creeping vines, plunging spines into the earth. Coconuts embark on sea journeys, carrying the weight of meat and milk, to germinate on the sands of far beaches. Dandelion seeds dance in the air, and the boxelder maple encases its seeds in thin wings, to glide gently down.

Hajar triggered the wings on the mech and leapt from a cliff, gliding in large loops until she touched down. The hands of the mech tested the air for breathability and temperature, and searched for spores.

Forward went the mech. Hajar read messages from the others. Nathaniel was heading north from a desert in the western hemisphere, while Denisa had found a promising sector near the equator. Arwa had done a fascinating preliminary survey of insects in a grassland biome. No one had heard from Suraya, aside from a terse message that she had touched down and was exploring, but she tended to go quiet on bad days.

They all carried their own secret griefs,

ready to bloom. Nathaniel refused to listen to Debussy, except for days when he would listen to nothing else, and the melody of 'Clair De Lune' floated across the ship. Arwa had a singular teacup, light green and decorated with fish, which she hid away in her quarters. Every member of the crew had left someone behind. They carried their grief in different ways: in photographs and letters, in knitted scarves and handwritten recipes, in ordinary objects

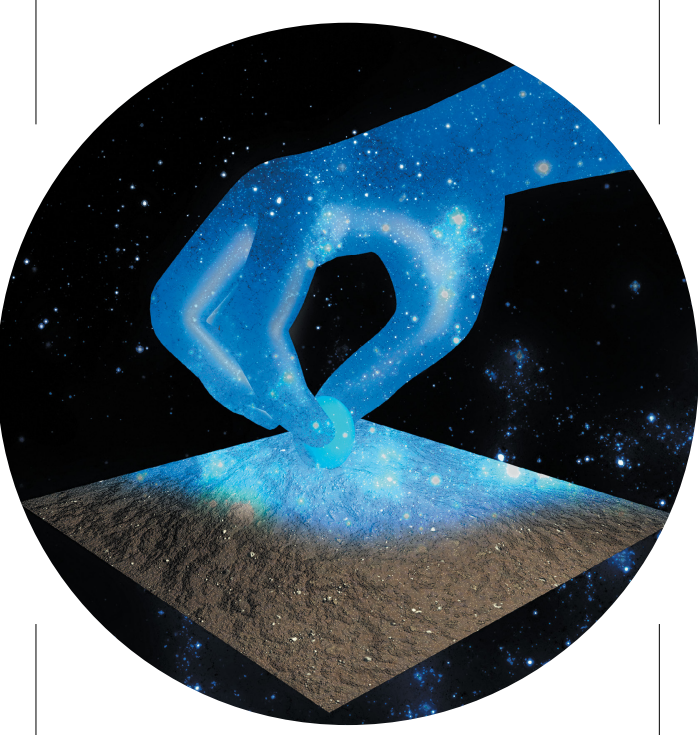

such as teacups and brooms, chipped pots and blue stones.

The mech marched onward under an alien sunset. When it grew too dark to see, Hajar halted the machine. She took the blue stone out of her pocket and turned it over. Before she left Earth, her father had folded the stone into her hands, his faded green hat tipped back, his hands smelling of cinnamon from baking. The stone had come from his garden, prised up from the mud. "Find a new place for it," he'd said, planting those words in the space meant for goodbyes. This was what she brought from Earth, what she carried.

Today, the stone felt rough against her fingers. She thought of her father, imagined the sound of the blender churning his breakfast, the worn leather of his hiking boots, his collection of rocks scattered over geology books on the kitchen counter.

Eventually, she slept, the stone clutched in

\section{ONATURE.COM}

Follow Futures:

@ @NatureFutures

$f$ go.nature.com/mtoodm her hand.

For her thesis, Hajar studied seed-dispersal strategies of
Oenothera deltoides, the bird-cage plant of Californian deserts.

The plant travels like this: as dunes shift, the roots are exposed. Shade melts away, leaving the plant under the light of an intolerable sun. The plant dies, curling its roots over itself: a bird cage, a wicker ball. Wind pulls the plant kilometres from its home. When the plant finds shelter from wind, seeds spill out from the lattice.

New plants rise, phoenix-like, from the husk.

The mech emerged in a clearing blanketed with grass. Three-petalled flowers bent in the wind.

The soil readings were good. A river rushed by to the east, the water potable.

Hajar sent a message to the others. A habitable zone to add to the list. She imagined all of them out in the meadow, tilling the soil, constructing houses from the durable bio-plastic they'd brought.

Hajar emerged from the mech. For the first time, she felt the planet's air on her face. The wind carried the smell of sunsimmered grass and wet soil.

Next to her, a tree thick with seeds wrapped in flexible coating, like a boxelder maple.

Once, her father had told her how seeds travel - to arid deserts and rich soil, through woodland and tundra, across oceans and rivers. By centimetres or kilometres, they go.

Not all of them survive.

Seeds travel, tumbling, falling, swept along until they cannot travel farther.

Where they land is home. They put down roots, they grow.

She wished her father was there. Seeds, she would tell him, are designed to travel, to seek out habitable spaces, leaving behind their progenitors, pushing forward into the wide future.

Hajar slipped the blue stone from her pocket. This place felt right, already full of life. How many seeds were even now under the soil, waiting to grow?

She clutched the stone close, then buried it in the soft earth. -

Beth Goder works as an archivist, processing the papers of economists, scientists and other interesting folk. Her fiction has appeared in venues such as Escape Pod, Fireside and an anthology from Flame Tree Press. You can find her online at http://www.bethgoder.com. 